\title{
APSA Announces New Teaching Web Site
}

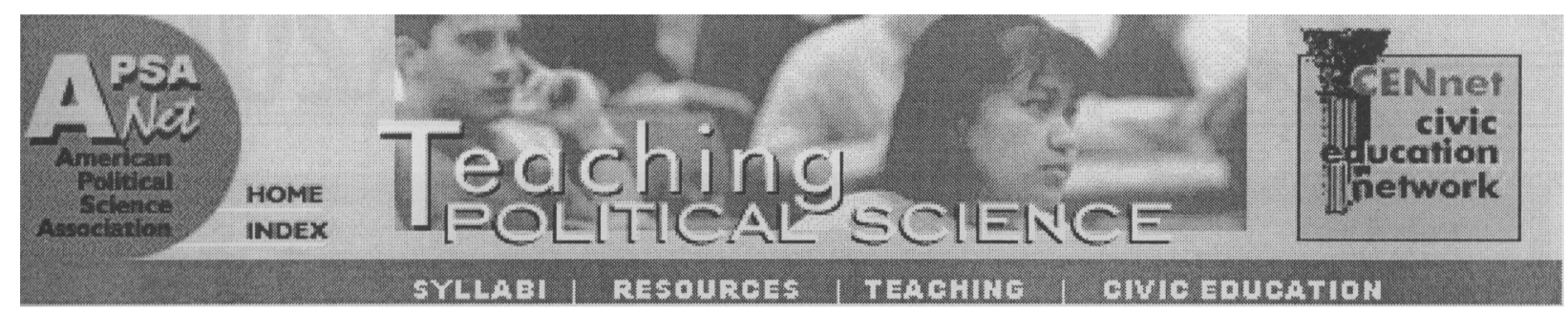

TEACHING POLITICAL SCIENCE

www.apsanet.org/teaching

APSA is pleased to announce the launch of its Teaching Political

Science web site-an online resource for political science scholars and teachers. Teaching Political Science is composed of four main sections: Syllabi, Resources, Teaching, and Civic Education.

The site contains a wealth of resources, including syllabi, articles on teaching and learning from past issues of $P S$, professional develop- ment opportunities for teachers, references for student research, and more. Special features are included throughout the site, such as the Site of the Month, highlighting web sites useful to political science faculty, and $O n$ the $W e b$, featuring innovations in technology for teaching. Materials from the Association's Task Force on Civic Education and a collection of civic education references and essays are also incorporated into the site.

Since resources contained on Teaching Political Science are continually expanding, visit the site often to see the latest materials and teaching innovations for political science. Faculty and students are encouraged to review the site and offer suggestions for additional content. Send your comments to: teaching@apsanet.org.

\section{Demonstration of 1999 PROceedings at Annual Meeting}

APSA invites Annual Meeting participants to view a demonstration of PROceedings: Political Research Online, the Association's digital collection of Annual Meeting papers, at the 1999 conference. The PROceedings web site (http:// pro.harvard.edu), developed and maintained by William J. Ball of The College of New Jersey, will be on display in the panel paper room of the Atlanta Marriott Marquis throughout the meeting.

PROceedings, a joint project of APSA, The College of New Jersey, and the Harvard University Library, debuted at the 1997 meeting in Washington, DC, and is funded by the Mellon Foundation. The site features more than 550 papers from the 1998 meeting. Visitors can search for papers by author, title, or keyword, or browse the Annual Meeting program, and can download their selections in PDF using Adobe Acrobat Reader (available free at www.adobe.com).

The 1998 papers will be available until August 13. Papers delivered during the 1999 meeting will be available starting August 16.

All 1999 paper authors are expected to submit electronic copies of their papers to PROceedings. An invitation to participate and submission instructions were mailed in May. If you have not received an invitation to post your Annual Meeting paper, please contact the PROceedings project team at proceedings@apsanet.org. Submission instructions will also be available on the submission web site (http://papers.tcnj.edu), after July 1, 1999. Authors can submit papers via the web site, email, or disk beginning July 1. Papers will be accepted through September 5.

The initial years of the PROceedings project will be critical in determining its ultimate success. Thus, authors are strongly encouraged to participate by submitting papers and by providing feedback on the process and on the project as a whole. Authors can submit papers to Bill Ball, Department of Political Science, The College of New Jersey, Hillwood Lakes CN 4700, Trenton, NJ 086504700; proceedings@apsanet.org.

\section{Travel Grants for 1999 Annual Meeting}

APSA will again offer a limited number of travel grants for advanced graduate students attending the Annual Meeting in Atlanta. Funded through the generosity of APSA members, the maximum award for any grant is $\$ 300$ and the money must be used for travel to the meeting. Grants will be awarded in two categories: (1) international graduate students attending U.S. institutions; and (2) advanced American graduate students presenting a paper or poster on the 1999 Program.

Interested students must complete a short application and submit a letter of support prepared by their department chair, graduate advisor, or graduate studies director. Applications without a letter of support will not be considered. Applicants who are furthest along in their course of study will be given greatest consideration. Previous winners are not eligible.

Applications are available via the APSA web site (www.apsanet. org/99AM/). Questions should be 
Campaign, 1903-2003

THE SPECIAL FUND FOR THE STUDY OF

WOMEN ANNE POLITICS

A New Giving Opportunity!

To support the study of women and politics. Income from the endowment will be used for the benefit of research residencies at the APSA Centennial Center and elsewhere in the field of women and politics.

https://doi.org/10.1017/S104909650004957X Published online by Cambridge University Press 


\section{APSA's Centernial}

\section{HHE JAMES BRYCE FUND}

\section{FOR}

\section{INTERNATIONAL POLITICAL \\ SCIENCE}

\section{A New Civing Oprortunity!}

To benefit the global study of political life and the internationalization of the political science discipline and profession. Income from this fund will support research residencies in the Centennial center and elsewhere, collaborative research workshops involving political scientists from the United States and abroad, teaching and curriculim development programs for emerging political science communities, and travel grants to the APSA Annual Meeting. 


\section{Annual Meeting Placement Service Available Online}

For the first time, the Annual Meeting Placement Service will be available on the web. Employers and job applicants are asked to submit their preregistration placement information via a web site specifically designed for the Placement Service at www.apsanet.org/placement/. Job applicants will also be provided with space to include an electronic copy of their resume. The target date for launch of this site is June 1, 1999.

The goal of this new service is to provide Placement Service participants with access to information before their travel to Atlanta. Applicants will be provided access to a searchable database of job openings upon completion of their preregistration. Employers who have registered online will be able to review candidates' applications and resumes before they travel to the Annual Meeting in Atlanta. It is expected that employers and candidates will be able to contact each other to arrange interviews prior to the meeting. This should eliminate the rush that usually occurs the first day of the meeting.

Preregistered employers will also be given the opportunity to reserve an interview table before the meeting. A limited number of computer terminals will be available for use in the Placement Service area, along with a full complement of binders containing paper copies of all applications and job listings.

Online preregistration for the Placement Service begins around June 1 and ends August 9. Employers who register at the meeting must bring their job information on an 3.5" IBM disk. Jobs registered at the meeting will be added to the database and copied into binders. Candidates who register at the meeting will only have paper copies of their application and resume available for review.

\section{Personnel Service Newsletter Submission Process Now Online}

Beginning in July 1999, a new format for submission of listings and a change in the submission deadline will take effect. Employers will be REQUIRED to submit jobs via the web (www.apsanet.org/PSN/). The deadline for submitting listings will be extended to the 10th of the month (e.g., July 10 for the August issue). Institutions without access to the web should use email or send a 3.5" IBM floppy disk to submit listings. Disks should be mailed to the attention of the PSN Editor at APSA. Additional information will be announced in upcoming issues of PSN and in the Chair's Newsletter. It is anticipated these changes vill eliminate transcription errors and ensure more efficient production.

\section{Subscription Price for PSN Greatly Reduced for Web Users}

Beginning in June, subscriptions to the Newsletter will be offered in two ways: $\$ 20.00$ for the web-only version, and $\$ 40$ for both the web and printed versions. Overseas combined web and printed subscriptions will be $\$ 65$.

Members opting for web-only access will enjoy a $43 \%$ decrease in the price of a subscription in comparison with the print newsletter. Because members who reside outside the U.S. must pay for air mail foreign delivery, their current rate is $\$ 60$. If these members choose the web option, their subscription fee will drop by two-thirds.

Instructions for accessing the web version will be printed in the Newsletter and available on the web. Access to the web version of PSN is limited to individual subscribers. Departments will continue to receive the printed version. directed to Sean Twombly at twombly@apsanet.org. The deadline for receipt of completed applications is July 2, 1999.

\section{Two-Participation Rule for Annual Meeting Modified}

The APSA Council, on the recommendation of the APSA Committee on the Annual Meeting, decided to relax the two-participation rule for program participants beginning with the 2000 Annual Meeting in an effort to ease the workloads of the 50 or so division chairs that put together the Annual Meeting program each year.

The two-participation rule, originally adopted by the Council in 1987 and modified in 1995, limited individuals to two appearances on the Annual Meeting program, and counted presenting a paper, serving as a discussant, and chairing a panel as an appearance. The limits were imposed to broaden participation in all divisions of the official program and related group panels. Since 1996, division chairs have argued that counting service as a panel chair unreasonably extends the time they must spend assembling division panels. After considering the issue for several years, the Annual Meeting Committee recommended to the Council that serving as a panel chair no longer be counted against the two-participation rule. The Council adopted the recommendation at its April 17 meeting.

\section{Submission Process}

The Council also supported the Committee recommendation that the dual submission rule permitting individuals to submit the same proposal to two different divisions for consideration should not be changed. It is often unclear which division is the most relevant substantive division to receive a particular panel or paper proposal. As a result, the Council decided against limiting submissions to a single division, though such a limitation would have substantially reduced the workload of division chairs.

The Council strongly endorsed the Committee's decision to move to- 